and served on many committees dealing with the teaching of aeronautics, as well as being a member of the Council of the Royal Aeronautical Society during 1935-39. His other interests included music-he was an able pianist-golf and the collecting of antiques.

H. F. WINNY

\section{Dr. Y. A. Bilibin}

YURy Alexandrovich BILIBIN was born on May 19, 1901, in Rostov in Yaroslav province, and he died on May 4, 1952, in Moscow. After active participation in the civil war of 1917-21, he graduated in 1926 at the Leningrad Mining Institute. His scientific work is intimately associated with the geological survey of Eastern Siberia, and he became an authority on the mode of occurrence and mode of origin of ores of gold, tin, copper and other metals. He constructed metallogenetic maps and lectured on metallogenetic provinces, and made considerable progress in the application of geochemistry to the problem of ore genesis. He also published important papers on the igneous rocks of the Aldan region in Eastern Siberia and was particularly interested in the origin of alkaline rocks. In 1943 he received his doctorate and was later elected a corresponding member of the Academy of Sciences. In 1948 he came to London to take part in the meeting of the International Geological Congress, and those who met him there will remember him as a shy but very friendly person who was an outstanding geochemist and geologist.

S. I. TOMKEIEFF

We regret to announce the following deaths :

Mr. Andrew Gray, technical general manager during 1928-32 of Marconi's Wireless Telegraph Co., Ltd., and an early assistant of Marconi, aged eighty.

Prof. J. W. McBain, F.R.S., emeritus professor of chemistry in Stanford University, California, and lately director of the National Chemical Laboratory, India, on March 12, aged seventy.

\section{NEWS \\ Agriculture in the University of Sydney: \\ Prof. W. L. Waterhouse}

Prof. W. L. WATERHoUSE, research professor in the Faculty of Agriculture, University of Sydney, retired at the end of 1952. During his thirty-two years of service, he had occupied the positions of lecturer, reader and professor. Prof. Waterhouse lectured on plant pathology, genetics and plant breeding, and agricultural botany. The scientific discipline derived from these courses was ideal, and has stood many graduates in good stead no matter in what field of scientific endeavour they work; his teaching was inspired. His main researches were in the field of cereal diseases, in which he accepted the challenge of solving the wheat rust problem of Australia. He had many successes, the culmination of his work from a practical point of view resulting in the production of an outstanding variety known as Gabo, which was resistant to all the forms of stem rust existent in Australia up to 1948. But perhaps his greatest contribution was to give a complete understanding of the problem, a thorough knowledge of the rusts, techniques for breeding resistant varieties, and above all hope for the future. Prof. Waterhouse has been a good colleague and has played a considerable part in developing the Faculty of Agriculture in the University of Sydney. Although handicapped by wounds sustained in the First World War when he was awarded the Military Cross, he never spared himself in his teaching and research. Prof. Waterhouse's work has been recognized by many awards: he was given the Farrer Memorial Medal in 1937 and again in 1950 ; in 1943 he received the Clarke Memorial Medal of the Royal Society of New South Wales, and in 1948 the Australian Medal of Agricultural Science. Now his University has conferred on him the title of emeritus professor. Truly can it be said that here is a man who has devoted himself to science and to agriculture, so that the lot of the farmer and the community might be improved and the world made a better place in which to live.

\section{n d VIEW S}

Geophysics at the Carnegie Institution of Washington : Dr. P. H. Abelson

Dr. Philip H. Abelson, chairman of the Biophysics Section of the Department of Terrestrial Magnetism in the Carnegie Institution of Washington, has been appointed director of the Geophysical Laboratory of the Institution with effect from September 1 next. Dr. Abelson's research career began under Prof. Ernest O. Lawrence at the University of California, Berkeley, where he made the initial identification of radioactive antimony, tellurium and iodine as products of uranium fission, gaining his Ph.D. in 1939. He then joined the Carnegie Institution as a staff member and took a prominent part in the design and construction of the cyclotron at its Department of Terrestrial Magnetism at Washington, D.C. During the Second World War he was a physicist at the Naval Research Laboratory, where he developed the liquid thermal diffusion method for enrichment of uranium-235, and under his general supervision a plant employing the method was designed and constructed at Oai Ridge for work in connexion with the atomic bomb. Dr. Abelson returned in 1946 to his old Department in the Carnegie Institution and organized a programme of biophysical work for using isotopes and radioactive nuclei in the study of the processes by which living cells select chemicals from their environment and organize them into new cells; as a result, a number of processes in the chemistry of amino-acids have beon elucidated. At the same time he has continued his interest in geophysics and geochemistry, and in his new post he is going to a laboratory where during recent years much of the work has been focused on novel experimental techniques for studying the physics and chemistry of the solid state, such as the melting and solubility relations of silicates, especially in the presence of water, and the transport of minerals by solution in a gas phase.

Dannie Heineman Prize of the Heineman Foundation

The first award of the Dannie Heineman Prize of the Heineman Foundation for Research, Educational, 